Journal of Pharmaceutical Science and Medical Reseaarch (PHARMED), 1 (2), 2018, 22-27

Available online at: http://e-journal.unipma.ac.id/index.php/pharmed

ISSN 2614-4840 (print) ISSN 2614-6118 (online)

\title{
Perbandingan Efektivitas Kaplet Antipiretik Dua Merek Dagang Parasetamol Dan Produk Generik Terhadap Mencit (Mus Musculus) Jantan
}

\author{
Ulfa Ni'ammah ${ }^{1}$, Nasruhan Arifianto ${ }^{2}$ \\ ${ }^{1}$ Akafarma Sunan Giri, Ponorogo, Indonesia \\ ${ }^{2}$ Prodi Farmasi Klinik, Fakultas Farmasi, Universitas Airlangga, Surabaya, Indonesia \\ E-mail: ulfaniamah32@gmail.com
}

Received 09/08, 2018; Accepted 08/10, 2018

\begin{abstract}
Abstrak
Antipiretik adalah obat yang dapat menekan atau mengurangi peningkatan temperatur tubuh yang tidak normal. Di pasaran, produk bermerek sering dianggap mempunyai mutu yang lebih tinggi dari produk generik, dan sering ditemukan pasien yang fanatik terhadap salah satu merek dagang tersebut. Padahal produk yang berada di pasaran telah melalui uji terhadap mutu produk tersebut.Untuk itu, dilakukan penelitian untuk membandingkan efektivitas antipiretik dari parasetamol bermerek dengan harga mahal, parasetamol bermerek dengan harga generik (murah) dan parasetamol generik pada mencit demam. Hewan coba dalam penelitian ini menggunakan mencit Mus musculus jantan.Tahapan penelitian pemberian perlakuan pada hewan coba meliputi; sebelum diberi perlakuan mencit diukur suhu rektalnya (suhu awal), kemudian disuntik dengan pepton 5\% secara subkutan. Satu jam kemudian suhu rektal kembali diukur, setelah itu mencit diberi perlakuan dengan bahan uji dan kontrol negatif. Hasil penelitian yang diperoleh berupa persentase daya antipiretik parasetamol bermerek dengan harga mahal, parasetamol bermerek dengan harga generik (murah) dan parasetamol produk generik berturut-turut sebesar 0,86\%, 1,07\% dan 0,41\% pada waktu pengamatan menit ke-60. Efek antipiretik parasetamol paling efektif digunakan untuk menurunkan suhu rektal mencit demam yaitu parasetamol merek B dan efektivitas terkecil terdapat pada parasetamol generik.
\end{abstract}

Kata kunci: Efektivitas, Parasetamol, Generik, Merek, Kaplet, Antipiretik, Induksi Pepton, Mencit.

\section{Comparative Antipyretic Caplet Effectiveness of Two Brands Mefenamat Acids and Generic Product of the Male Mice (Mus musculus) with Pepton Induction}

\begin{abstract}
Paracetamol is a widely used chemical compound because it has the ability to lower body temperature to normal. In the market, branded products are often considered to be of higher quality than generic products, and are often found by patients who are fanatical towards one of these trademarks. Though the products on the market have been through the test of the quality of these products. Therefore, a study was conducted to compare the antipyretic effectiveness of branded paracetamol at high prices, branded paracetamol at generic (cheap) prices and generic paracetamol in febrile mice. Animal tried in this using male Mus musculus mice. Stages of research on the treatment of animals try to include; before treatment of mice was mesuared at rectal temperature (initial temperature), then injected with 5\% pepton subcutaneously. An hour later the rectal temperature was again measured, after which the mice were treated with negative test and control material. The result showed that the percentage of antipyretic power of branded paracetamol with high price, paracetamol branded with generic price (cheap) and paracetamol of generic product were $0.86 \%, 1.07 \%$ and $0.41 \%$ at the observation time of the 60th minute. The most effective antipyretic effect of paracetamol is used to lower the rectal temperature of febrile mice is on brand paracetamol $B$ and the smallest effectivity is found in the generic paracetamol.
\end{abstract}

Keywords: Effectiveness, Paracetamol, Generic, Brand, Kaplet, Antipyretic, Pepton, Induction, Mice. 
Journal of Pharmaceutical Science and Medical Reseaarch (PHARMED), 1 (2), 2018, 22-27

Available online at: http://e-journal.unipma.ac.id/index.php/pharmed

ISSN 2614-4840 (print) ISSN 2614-6118 (online)

\section{PENDAHULUAN}

Antipiretik adalah obat yang dapat menekan atau mengurangi peningkatan temperatur tubuh yang tidak normal (Ganong, 2005). Antipiretik yang sering digunakan adalah parasetamol. Parasetamol merupakan senyawa kimia yang banyak digunakan karena memiliki kemampuan untuk menurunkan suhu tubuh ke keadaan normal (Neal, 2002). Produk parasetamol yang beredar di masyarakat adalah parasetamol bermerek dengan harga mahal, parasetamol bermerek dengan harga generik (murah), serta parasetamol produk generik.

Di pasaran, produk bermerek sering dianggap mempunyai mutu yang lebih tinggi dari produk generik, dan sering ditemukan pasien yang fanatik terhadap salah satu merek dagang tersebut. Hal ini disebabkan pasien menganggap bahwa obat bermerek dengan harga jual yang mahal mempunyai khasiat yang cepat dalam menurunkan demam. Padahal produk yang berada di pasaran telah melalui uji terhadap mutu produk tersebut. Berdasarkan uraian diatas peneliti melakukan uji efektivitas antipiretik pada parasetamol bermerek dengan harga mahal, parasetamol bermerek dengan harga generik (murah) dan parasetamol produk generik. Dalam penelitian ini digunakan metode induksi pepton oleh karena murah, mudah didapat dan tidak toksik. Senyawa pepton bersifat pirogen (suatu zat yang menyebabkan demam) sehingga dapat meningkatkan suhu tubuh hewan coba (Budiman, 2010). Pengujian efektivitas akan dilakukan dengan cara induksi pepton secara subcutan untuk meningkatkan suhu tubuh hewan cobamencit (Barnes, 1964). Penelitian ini menggunakan mencit (Mus musculus) jantan dewasa karena hewan ini merupakan hewan yang memiliki alat pencernaan dan kebutuhan nutrisi yang hampir sama dengan manusia, pemeliharaan cukup mudah dan dapat mewakili mamalia termasuk manusia (Malole, 1989).

\section{METODE}

\section{Alat dan Bahan}

Alat yang digunakan : jarum suntik (Thermo $1 \mathrm{ml}$ ), neraca analitik neraca analitik (Ohaus PA224), thermometer digital (ThermoONE Alpha 1), stopwatch, pipet volume $10 \mathrm{ml}$ (Iwaki), dan alat-alat gelas laboratorium,
Bahan yang digunakan : tablet parasetamol generik, pepton $5 \%$, aqua pro injeksi, CMC-Na $1 \%$, alkohol $70 \%$, dan mencit putih jantan.

\section{Prosedur Kerja}

Sebelum digunakan, hewan uji terlebih dahulu diadaptasikan selama satu minggu di kandang. Mencit yang sehat memiliki ciri-ciri bulu bersih dan tidak berdiri, mata jernih bersinar, dan berat badan bertambah atau tidak berkurang setiap harinya. Mencit yang dinyatakan sehat dikelompokkan secara acak dengan jumlah 6 ekor tiap kelompok (Riza, 2012).

Pemberian senyawa pada hewan coba (mencit) memiliki dosis maksimum yaitu $4000 \mathrm{mg} / \mathrm{Kg}$ BB dan batas maksimum volume cairan yang boleh diberikan pada hewan uji sebesar 0,5 $\mathrm{ml}$ (Thomson,1990).

Pada tahap awal, memilih mencit yang akan digunakan, kemudian menimbangnya. Kemudian mengukur suhunya awal sebelum di induksi dengan pepton 5\% 0,01 $\mathrm{ml} / \mathrm{gram}$ BB secara subkutan. Setekah itu, mengukur suhu rektal mencit kembali, untuk mengetahui peningkatan suhu akibat penyuntikkan pepton maka 5 menit sebelum perlakuan diberikan. Satu jam kemudian setelah pemberian pepton, memberikan senyawa pada mencit berdasarkan tabel berikut,

Tabel 1 Kelompok Senyawa Uji

\begin{tabular}{|c|c|}
\hline Kelompok & Senyawa \\
\hline 1 & $\begin{array}{c}\text { Suspensi Na-CMC } \\
1 \%\end{array}$ \\
\hline 2 & Parasetamol merek A \\
\hline 3 & Parasetamol merek B \\
\hline 4 & Parasetamol generik \\
\hline
\end{tabular}

Pemberian senyawa uji berdasarkan rumus,

BB $(\mathrm{Kg})$ x Dosis $(\mathrm{mg} / \mathrm{kgBB})$

Kadar sediaan $(\mathrm{mg} / \mathrm{ml})$ 
Pada setiap penyuntikan tiap mencit dilakukan penggantian jarum suntik. Lima belas menit sejak perlakuan, suhu rektal mencit diukur kembali, sampai menit ke-90 dengan interval 15 menit untuk mengetahui penurunan suhu.

\section{HASIL DAN PEMBAHASAN}

Data rata-rata suhu rektal mencit pada pemberian perlakuan uji efektivitas antipiretik pada kontrol negatif, sediaan parasetamol merek A, parasetamol merek B, dan parasetamol generic dapat dilihat pada tabel berikut:

Tabel 2 Suhu Rektal Mencit pada Kelompok Kontrol Na-CMC 1\%

\begin{tabular}{|c|c|c|c|c|c|c|c|c|c|c|}
\hline \multirow{2}{*}{ Mencit } & \multirow{2}{*}{\begin{tabular}{|c|} 
Berat \\
Badan $(\mathrm{g})$
\end{tabular}} & \multirow{2}{*}{$\begin{array}{l}\text { Suhu } \\
\text { awal }\end{array}$} & \multirow{2}{*}{$\begin{array}{l}\text { Pepton } \\
5 \%(\mathrm{ml})\end{array}$} & \multirow{2}{*}{$\begin{array}{c}\text { Demam } \\
\text { awal }\end{array}$} & \multicolumn{6}{|c|}{ Waktu pengamatan menit ke- } \\
\hline & & & & & 15 & 30 & 45 & 60 & 75 & 90 \\
\hline 1 & 23 & 36.4 & 0,23 & 37.1 & \begin{tabular}{|l}
37.1 \\
\end{tabular} & 37.1 & 5 & 1.4 & 37.3 & 37.1 \\
\hline 2 & & & & & 3 & 37.4 & & 4 & 37.3 & 37.3 \\
\hline 3 & & & 0,22 & & 36.9 & 3 & & 0 & 36.9 & 3 \\
\hline 4 & & 4 & 4 & & 37.4 & 37.4 & 37.5 & 37.5 & 37.4 & 37.4 \\
\hline 5 & & & & & 37.6 & 37 & & 37. & 37.4 & 37.4 \\
\hline 6 & & & 0,25 & & 3 & & & .5 & 37.4 & 37.4 \\
\hline & & 36.4 & 0,24 & 37.13 & 37.28 & 37.32 & 37.47 & 37.40 & 37.28 & 37.25 \\
\hline
\end{tabular}

Data di atas merupakan data suhu dalam ${ }^{\circ} \mathrm{C}$

\section{Keterangan:}

Demam awal $=$ suhu rektal 1 jam setelah diinduksi pepton

Tabel 3 Suhu Rektal Mencit pada Kelompok Parasetamol Merek A

\begin{tabular}{|c|c|c|c|c|c|c|c|c|c|c|c|}
\hline \multirow{2}{*}{ Mencit } & $\begin{array}{c}\text { Berat } \\
\text { Badan(g) }\end{array}$ & $\begin{array}{c}\text { Suhu } \\
\text { awal }\end{array}$ & $\begin{array}{l}\text { Pepton } \\
\mathbf{5 \%}(\mathbf{m l})\end{array}$ & $\begin{array}{c}\text { Demam } \\
\text { awal }\end{array}$ & $\begin{array}{l}\text { Parasetamol } \\
\text { merek A(ml) }\end{array}$ & \multicolumn{6}{|c|}{ Waktu pengamatan menit ke- } \\
\hline 1 & 22 & 36.5 & 0,22 & 37.5 & 0,29 & 37.6 & 37.5 & 37.5 & 37.4 & 37.4 & 37.3 \\
\hline 2 & 23 & 36.2 & 0,23 & 37.2 & 0,30 & 37.5 & 37.3 & 37.3 & 36.9 & 37.0 & 37.0 \\
\hline 3 & 24 & 36.4 & 0,24 & 37.5 & 0,31 & 37.6 & 37.5 & 37.4 & 37.4 & 37.4 & 37.3 \\
\hline 4 & 22 & 36.3 & 0,22 & 36.9 & 0,29 & 36.9 & 3.8 & 36.8 & 36.8 & 36.7 & 36.8 \\
\hline 5 & 23 & 36.3 & 0,23 & 37.1 & 0,30 & 37.2 & 37.0 & 37.1 & 36.9 & 36.8 & 36.7 \\
\hline 6 & 25 & 36.4 & 0,25 & 37.2 & 0,33 & 37.1 & 37.2 & 37.2 & 37.1 & 37.1 & 37.1 \\
\hline \multicolumn{2}{|c|}{ Rata-rata } & 36.35 & 0,23 & 37.23 & 0,33 & 37.32 & 37.22 & 37.20 & 37.08 & 37.07 & 37.03 \\
\hline
\end{tabular}

Data di atas merupakan data suhu dalam ${ }^{\circ} \mathrm{C}$

\section{Keterangan:}

Demam awal $=$ suhu rektal 1 jam setelah diinduksi pepton

Tabel 4 Suhu Rektal Mencit pada Kelompok Parasetamol Merek B

\begin{tabular}{|c|c|c|c|c|c|c|c|c|c|c|c|}
\hline \multirow{2}{*}{ Mencit } & \multirow{2}{*}{$\begin{array}{c}\text { Berat } \\
\text { Badan }(g)\end{array}$} & \multirow{2}{*}{$\begin{array}{l}\text { Suhu } \\
\text { awal }\end{array}$} & \multirow{2}{*}{\multicolumn{2}{|c|}{$\begin{array}{l}\text { Pepton Demam } \\
5 \%(\mathrm{ml}) \text { awal }\end{array}$}} & \multirow{2}{*}{$\begin{array}{l}\text { Parasetamol } \\
\text { merek B(ml) }\end{array}$} & \multicolumn{6}{|c|}{ Waktu pengamatan menit ke- } \\
\hline & & & & & & 15 & 30 & 45 & 60 & 75 & 90 \\
\hline 1 & 23 & 36.5 & 0,23 & 37.3 & 0,30 & 37.4 & 37.2 & 37.2 & 37.1 & 36.9 & 36.8 \\
\hline 2 & 25 & 36.6 & 0,25 & 37.5 & 0,33 & 37.3 & 37.1 & 37.1 & 36.1 & 36.8 & 36.8 \\
\hline 3 & 22 & 36.5 & 0,22 & 37.3 & 0,27 & 37.0 & 37.1 & 37.1 & 37.2 & 37.2 & 37.2 \\
\hline 4 & 23 & 36.7 & 0,23 & 37.2 & 0,30 & 37.0 & 37.0 & 37.0 & 36.8 & 37.0 & 36.8 \\
\hline 5 & 24 & 36.6 & 0,24 & 37.1 & 0,31 & 36.9 & 37.1 & 37.1 & 36.9 & 37.0 & 36.8 \\
\hline 6 & 24 & 36.6 & 0,24 & 37.0 & 0,31 & 36.9 & 37.0 & 37.0 & 36.9 & 36.9 & 36.8 \\
\hline \multicolumn{2}{|c|}{ Rata-rata } & 36.58 & 0,24 & 37.23 & 0,31 & 37.08 & 37.12 & 37.08 & 37.00 & 37.07 & 36.87 \\
\hline
\end{tabular}

Data di atas merupakan data suhu dalam ${ }^{\circ} \mathrm{C}$

\section{Keterangan:}


Journal of Pharmaceutical Science and Medical Reseaarch (PHARMED), 1 (2), 2018, 22-27

Available online at: http://e-journal.unipma.ac.id/index.php/pharmed

ISSN 2614-4840 (print) ISSN 2614-6118 (online)

Demam awal $=$ suhu rektal 1 jam setelah diinduksi pepton

Tabel 5 Suhu Rektal Mencit pada Kelompok Parasetamol Generik

\begin{tabular}{|c|c|c|c|c|c|c|c|c|c|c|c|}
\hline \multirow{2}{*}{ Mencit } & \multirow{2}{*}{$\begin{array}{c}\text { Berat } \\
\text { Badan }(\mathrm{g})\end{array}$} & \multirow{2}{*}{$\begin{array}{l}\text { Suhu } \\
\text { awal }\end{array}$} & \multirow{2}{*}{$\begin{array}{l}\text { Pepton } \\
5 \%(\mathrm{ml})\end{array}$} & \multirow{2}{*}{$\begin{array}{c}\text { Demam } \\
\text { awal }\end{array}$} & \multirow{2}{*}{$\begin{array}{c}\text { Parasetamol } \\
\text { generik }(\mathrm{ml})\end{array}$} & \multicolumn{6}{|c|}{ Waktu pengamatan menit ke- } \\
\hline & & & & & & 15 & 30 & 45 & 60 & 75 & 90 \\
\hline 1 & 25 & 36.4 & 0,25 & 37.2 & 0,33 & 37.5 & 37.3 & 37.4 & 37.3 & 37.2 & 37.0 \\
\hline 2 & 24 & 36.5 & 0,24 & 37.3 & 0,31 & 37.1 & 37.1 & 37.3 & 36.2 & 37.2 & 37.1 \\
\hline 3 & 23 & 36.4 & 0,23 & 37.3 & 0,30 & 37.3 & 37.3 & 37.3 & 37.3 & 37.2 & 37.0 \\
\hline 4 & 24 & 36.6 & 0,24 & 37.4 & 0,31 & 37.4 & 37.5 & 37.5 & 37.4 & 37.3 & 37.1 \\
\hline 5 & 24 & 36.3 & 0 & 2 & 0, & 37.1 & 37.1 & 37.2 & 37.2 & 37.1 & 37.0 \\
\hline 6 & 21 & 36.3 & 0,21 & 37.3 & 0,27 & 37.3 & 37.3 & 37.2 & 37.1 & 37.0 & 37.0 \\
\hline & & 36.42 & 0,24 & 37.28 & 0,30 & 37.28 & 37.27 & 37.32 & 37.08 & 37.32 & 37.25 \\
\hline
\end{tabular}

Data di atas merupakan data suhu dalam ${ }^{\circ} \mathrm{C}$

\section{Keterangan:}

Demam awal $=$ suhu rektal 1 jam setelah diinduksi pepto

Dari tabel suhu rektal mencit di atas, tampak bahwa suhu rektal mencit pada kelompok senyawa uji parasetamol lebih rendah bila dibandingkan dengan suhu rektal mencit kelompok kontrol negatif, sehingga dapat dikatakan bahwa senyawa uji dapat menurunkan demam atau memiliki aktivitas antipiretik.Suhu rektal mencit pada kelompok senyawa uji tampak bahwa suhu rektal mencit tiap kelompok berbeda, sehingga dapat dikatakan bahwa senyawa uji memiliki efektivitas yang berbeda.

Tabel 6 Suhu Rata-Rata Rektal Mencit

\begin{tabular}{|c|c|c|c|c|c|c|c|c|}
\hline Sampel & $\begin{array}{c}\text { Suhu } \\
\text { awal }\end{array}$ & $\begin{array}{c}\text { Suhu } \\
\text { demam }\end{array}$ & $\begin{array}{c}\text { Menit } \\
\text { ke-15 }\end{array}$ & $\begin{array}{c}\text { Menit } \\
\text { ke-30 }\end{array}$ & $\begin{array}{c}\text { Menit } \\
\text { ke-45 }\end{array}$ & $\begin{array}{c}\text { Menit } \\
\text { ke-60 }\end{array}$ & $\begin{array}{c}\text { Menit } \\
\text { ke-75 }\end{array}$ & $\begin{array}{c}\text { Menit } \\
\text { ke-90 }\end{array}$ \\
\hline Kontrol (Na-CMC 1\%) & 36.4 & 37.13 & 37.28 & 37.32 & 37.47 & 37.4 & 37.28 & 37.25 \\
\hline Parasetamol merek A & 36.35 & 37.23 & 37.32 & 37.22 & 37.2 & 37.08 & 37.07 & 37.03 \\
\hline Parasetamol merek B & 36.58 & 37.23 & 37.08 & 37.12 & 37.08 & 37.00 & 37.07 & 36.87 \\
\hline Parasetamol generik & 36.42 & 37.28 & 37.28 & 37.27 & 37.32 & 37.08 & 37.32 & 37.25 \\
\hline
\end{tabular}

Data di atas merupakan data suhu dalam ${ }^{\circ} \mathrm{C}$

Berdasarkan rata-rata dari keseluruhan data tabel di atas bahwa dari kelompok yang paling efektif dalam penurunan demam terdapat pada kelompok yang diberikan parasetamol merek B sehingga dapat disimpulkan bahwa parasetamol merek B memiliki efek antipiretik lebih besar dibanding parasetamol merek A dan parasetamol generik. Parasetamol merek A dan Parasetamol merek B memiliki efektivitas daya antipiretik pada waktu pengamatan menit ke-60 sedangkan untuk parasetamol generik memiliki efektivitas daya antipiretik terbesar pada waktu pengamatan menit ke-90.

\section{KESIMPULAN}

Parasetamol merek A, parasetamol merek B dan parasetamol produk generik memiliki perbandingan kekuatan efektivitas antipiretik yang berbeda sehingga berdasarkan metode yang digunakan dalam penelitian ini, pada parasetamol merek A dengan kadar $104,40 \%$ (b/b) memiliki persen daya antipiretik sebesar $0,86 \%$ pada waktu pengamatan menit ke-60 dan 0,64\% pada waktu pengamatan menit ke-90. Pada parasetamol merek B dengan kadar 108,10\% (b/b) memiliki persen daya antipiretik sebesar $1,07 \%$ pada waktu pengamatan menit ke-60 dan $1,02 \%$ pada menit ke-90. Pada parasetamol generik dengan kadar $103,51 \%$ (b/b) memiliki persen daya antipiretik sebesar $0,41 \%$ pada waktu pengamatan menit ke60 dan $0,64 \%$ pada waktu pengamatan menit ke90. Efektivitas antipiretik terbesar terjadi pada produk parasetamol merek B dan efektivitas antipiretik terkecil terjadi pada parasetamol produk generik. 
Journal of Pharmaceutical Science and Medical Reseaarch (PHARMED), 1 (2), 2018, 22-27

Available online at: http://e-journal.unipma.ac.id/index.php/pharmed

ISSN 2614-4840 (print) ISSN 2614-6118 (online)

\section{UCAPAN TERIMA KASIH}

Penulis ingin menyampaikan ucapan terimakasih kepada pihak-pihak yang sangat mendukung penulis dalam pembuatan dan penyusuan karya tulis ilmiah ini, adapun yang dimaksud adalah kepada Allah SWT, kedua orang tua, kepada saudara-saudara yang telah member dukungan dan kepada pihak-pihak yang telah membantu terselesainya penelitian ini.

\section{DAFTAR PUSTAKA}

Almaitser, Sunita. 2002. Prinsip Dasar Ilmu Gizi. Jakarta: PT. Gramedia Pustaka Utama.

Anief, M. 1997. Apa yang Perlu Diketahui tentang Obat. Yogyakarta: Gadjah Mada University Press.

Anonim. 2014. Farmakope Indonesia. Edisi 5. Jakarta: Kementerian Kesehatan Republik Indonesia.

Barnes, J.M., Paget, G.E. 1964. Evaluation of Drug Activities. Laurance, D.R., Bacharach, A.L., eds. New York: Academic Press.

Bickley, L.S., and Szilagyi, P.G. 2006. Physical Examination and History Taking, $9^{\text {th }}$ ed. Philadelphia: Lippincott William \& Wilkins.

Cheftel J.C. 1979. Amino Acids, Peptides, and Proteins. New York: Marcel Deker, Inc.

Dalal S. and Zhukovsky D.S. 2006. Pathophysiology and Management of Fever. J. Support Oncol 2006. 4: 009016.

Fennema, O.R. 1986. Principle of Food Science. New York: Marcel Dekker Inc.

Freddy I. dan Wilmana. 2007. Analgesic, Antipiretik, Antiinflamasi Non Steroid dan Obat Pirai. Farmakologi dan Terapi, Edisi 5. Jakarta: Bagian Farmakologi Fakultas Kedokteran Universitas Indonesia.
Ganong, W.F. 2005. Pengaturan Sentral Fungsi Visera. Buku Ajar Fisiologi Kedokteran. Edisi 22. Alih bahasa: M. Djauhari W. Jakarta: Penerbit Buku Kedokteran EGC. Hal. 236-237.

Gelfand, J.A. 2005. Fever and Hyperthermia. In: Kasper DL, Fauci AS, Longo DL, Braunwald E, Hauser SL, Jameson J (eds). Harrison's Principles of Internal Medicine. $16^{\text {th }}$ Ed. Vol II. New York: The McGraw-Hill Companies.

Guyton, A.C. 2007. Suhu Tubuh, Penhgaturan Suhu Tubuh, dan Demam. Buku Ajar Fisiologi Kedokteran. Edisi 11. Alih Bahasa: Petrus Adrianto. Jakarta: Penerbit Buku Kedokteran EGC.

Katzung B.G. dan Payan D.G. 1998. Obat Antiinflamasi Non-Steroid, Analgetik Non-Opioid, Obat yang Digunakan pada Gout. Dalam: Awar Agoes, dkk (eds). Farmakologi Dasar dan Klinik Bertram G. Katzung. Edisi 6. Jakarta: Penerbit Buku Kedokteran EGC.

Kemenkes. 2013. Riset Kesehatan Dasar. Jakarta: Badan Penelitian dan Pengembangan Kesehatan Kementrian Republik Indonesia.

Kurbanoglu, Basaran E., Omer Faruk Algur. 2001. Use of Ram Horn Hydrolysate as Pepton for Bacterial Growth. J Biol. Vol 26. Hal. 115-123.

Malole M.B.B. dan Pramono, S.C.U. 1989. Penanganan Hewan Percobaan di Laboratorium Universitas Bioteknologi. Bandung: Institut Teknologi Bandung.

Martijo. 1992. Kesehatan dan Kemampuan Adaptasi Hewan. Yogyakarta: Universitas Gajdah Mada.

Moffat, A.C., Osselton, M.D., dan Widdop, B. 2005. Clarke's Analysis of Drugs and Poissons. Edisi 3. London: Pharmaceutical Press. 
Journal of Pharmaceutical Science and Medical Reseaarch (PHARMED), 1 (2), 2018, 22-27

Available online at: http://e-journal.unipma.ac.id/index.php/pharmed

ISSN 2614-4840 (print) ISSN 2614-6118 (online)

Murakami M. and Kudo I. 2004. Recent Advances in Molecular Biology and Physiology of The Prostaglandin $\mathrm{E}_{2-}$ Biosynthetic Pathway. Prog Lipid Res. Vol. 43. Hal. 3-35.

Neal. M.J. 2002. At a Glace Farmakologi Medis. Edisi 5. Jakarta: Erlangga.

Nelwan R. H. 2006. Demam: Tipe dan Pendekatan. Dalam: A.W. Sudoyo, dkk (eds). Buku Ajar Ilmu Penyakit Dalam. Jilid 3. Edisi 4. Jakarta: Pusat Penerbitan Ilmu Penyakit Dalam Fakultas Kedokteran Universitas Indonesia.

Ngatidjan. 1991. Petunjuk Laboratorium, Metode Laboratorium dalam Toksikologi. Yogyakarta: Universitas Gadjah Mada.

Priyambodo, S. 1995. Pengendalian Hama Tikus Terpadu. Jakarta: Penebar Swadaya.

Sherwood, L. 2001. Keseimbangan Tubuh dan Pengaturan Suhu. Fisiologi Manusia: Dari Sel ke Sistem. Edisi 2. Alih bahasa: Brahm U.P. Jakarta: Penerbit Buku Kedokteran EGC.

Simmons D.L., Botting R.M., Hla T. Cyclooxygenase Isozymes: The Biology of Prostaglandin Synthesis and Inhibition. Pharmacrol Rev. Vol. 56. Hal. 387-437.

Syaifuddin. 2009. Anatomi Tubuh Manusia untuk Mahasiswa Keperawatan. Edisi 2. Jakarta: Salemba Medika.

Tamsuri, Anas. 2007. Tanda-Tanda Vital Suhu Tubuh. Jakarta: EGC Buku Kedokteran.

Thompson, E.B. 1990. Drug Bioscreening, Fundamental of Drug Evaluation Techniques in Pharmacology. New York: VCH Publisher Inc, Hal. 23, 41-42, 6783.

Thompson H.J. 2005. Fever a Concept Analysis. $J$ Ads Nurs 2005. Vol 5. Hal. 484-492.

Vogel, H.G. 2008. Drug Discovery and Evaluation Pharmacologycal Assays.
Springer-Verley Berlin. New York: Deidelbarg 
